\title{
Validation of an educational booklet for people with chronic pain: EducaDor
}

\author{
Validação de uma cartilha educativa para pessoas com dor crônica: EducaDor
}

Ana Shirley Maranhão Vieira ${ }^{1}$, Kamyle Villa-Flor de Castro² ${ }^{2}$ Janine Ribeiro Canatti ${ }^{2}$, lasmyn Adélia Victor Fernandes de Oliveira ${ }^{2}$, Silvia Damasceno Benevides ${ }^{2}$, Katia Nunes Sá1

DOI 10.5935/2595-0118.20190008

\section{ABSTRACT}

BACKGROUND AND OBJECTIVES: Socio-educational tools aimed at the population with chronic pain can help in the knowledge about trigger mechanisms, beliefs, and attitudes towards pain that may be useful in their control. In addition to developing them, it is necessary to evaluate whether these tools are valid for therapeutic use. The objective of this study was to describe the validation process of an educational booklet for people with chronic pain.

METHODS: This study was developed in three stages: questionnaires for the evaluation of the booklet by patients and professionals, interview, and content validation. The sample consisted of 60 patients with chronic pain and six professionals specialized in your treatment. For validation, the Content Validity Index per items was used considering a score greater than or equal to $80 \%$. RESULTS: All six domains evaluated in the booklet obtained a Content Validity Index per items score greater than $80 \%$. The Content Validity Index per items overall rate of the domains evaluated by the patients was $88 \%$ while for the health professionals it was $92 \%$.

CONCLUSION: The EducaDor booklet showed to be valid for use in the education of patients with chronic pain.

Keywords: Chronic pain, Health education, Validation study.

Ana Shirley Maranhão Vieira - (Dhttps://orcid.org/0000-0002-7170-4203;

Kamyle Villa-Flor de Castro - (1) https://orcid.org/0000-0001-8496-4576;

Janine Ribeiro Canatti - (Dhttps://orcid.org/0000-0002-5726-8388;

Iasmyn Adélia Victor Fernandes de Oliveira - Dhttps://orcid.org/0000-0003-0180-5997;

Silvia Damasceno Benevides - (Dhttps://orcid.org/0000-0002-4877-0835;

Katia Nunes Sá - (Dhttps://orcid.org/0000-0002-0255-4379.

1. Escola Bahiana de Medicina e Saúde Pública, Salvador, BA, Brasil.

2. Universidade Federal da Bahia, Instituto de Ciências da Saúde, Salvador, BA, Brasil.

Submitted in September 10, 2018.

Accepted for publication in December 10, 2018.

Conflict of interests: none - Sponsoring sources: none

Correspondence to:

Katia Nunes Sá

Av. D. João VI, 275 - Brotas

40290-000, Salvador, BA, Brasil.

E-mail: katia.sa@gmail.com

E-mail: asmvieira@bahiana.edu.br

(c) Sociedade Brasileira para o Estudo da Dor

\section{RESUMO}

JUSTIFICATIVA E OBJETIVOS: Ferramentas socioeducativas voltadas para a população com dor crônica podem auxiliar no conhecimento sobre mecanismos desencadeantes, crenças e atitudes frente à dor, que podem ser úteis no seu controle. Além de desenvolvê-las, se faz necessário avaliar se essas ferramentas são válidas para o uso terapêutico. $\mathrm{O}$ objetivo deste estudo foi descrever o processo de validação de uma cartilha educativa para pessoas com dor crônica.

MÉTODOS: Este estudo foi desenvolvido em três etapas: construçáo de questionários para avaliação da cartilha por pacientes e profissionais, entrevista e validaçáo de conteúdo. A amostra consistiu de 60 pacientes com dor crônica e seis profissionais especializados no seu tratamento. Para validação, foi utilizado o Índice de Validade de Conteúdo por itens considerando um escore maior ou igual a $80 \%$.

RESULTADOS: Todos os seis domínios avaliados na cartilha obtiveram escore do Índice de Validade de Conteúdo por itens maior que $80 \%$. A taxa global do Índice de Validade de Conteúdo por itens dos domínios avaliados pelos pacientes foi de $88 \%$ enquanto que para os profissionais de saúde foi de $92 \%$.

CONCLUSÁO: A cartilha EducaDor mostrou-se válida para o uso na educaçáo de pacientes com dor crônica.

Descritores: Dor crônica, Educação em saúde, Estudo de validação.

\section{INTRODUCTION}

Chronic pain (CP) is defined as "a stressful experience associated with an actual or potential tissue injury with sensory, emotional, cognitive and social components" ${ }^{1}$ that lasts for more than six months, with daily or almost daily frequency. In Brazil, CP is considered a public health problem with a high incidence and prevalence $^{2}$. CP impacts more than $40 \%$ of the Brazilian population $^{3,4}$.

The multifactorial nature of $\mathrm{CP}$ calls the need for new preventive and therapeutic modalities for its control. Thus, the use of multidimensional approaches involving biological, psychological, and social aspects, as well as health education activities that address these biopsychosocial aspects may result in immediate and late benefits. This effect was superior to those obtained with conventional interventions, such as drugs and physiotherapy ${ }^{5,6}$.

Making people aware of the meaning of pain, how it behaves, its common causes, risk factors, and how to prevent or treat it effectively may contribute to control the symptoms and optimize the use of health services ${ }^{6-8}$. 
Different methods have been adopted to carry out educational processes in the health area, including the distribution of booklets, personal construction studies, videos, group activities, and lectures $^{6,9-11}$. However, the literature is scarce on approaches that use written educational materials, such as booklets involving guidelines for the treatment of patients with CP. Through booklets, patients, family and caregivers can get the knowledge about the situations that trigger pain and what to do to help minimize it ${ }^{12,13}$. Thinking about this, Mendez et al. ${ }^{14}$ developed a booklet for education in CP, called EducaDor, which goes beyond the purely biomedical model of their approach. The booklet explains pain from its concept to its processing, simply and objectively, and proposing coping strategies. Aiming at the use of the booklet in an extended way in clinical practice, the objective of this study was to validate a socio-educative booklet on CP by patients and health professionals.

\section{METHODS}

This is a study to validate a light technology in health, conducted at the Pain Outpatient Clinic of the University Hospital Professor Edgar Santos (HUPES) of the Federal University of Bahia (UFBA), from June 2015 to November 2016.

Semi-structured questionnaires were elaborated and applied in a voluntary sample of patients with CP and health professionals with experience in assisting this profile of patients to validate the booklet. Among the professional team of the outpatient clinic, six professional who met the eligibility criteria were selected as judges, as suggested by Joventino et al. ${ }^{15}$. The validation by the target audience was done with 10 patients per health professional, totaling 60 patients.

Patients enrolled in the HUPES/UFBA Pain Outpatient Clinic were included, with a diagnosis of CP, literate, aged between 18 and 60 years. Those who did not understand the evaluation instrument were excluded. We included healthcare professionals with a minimum of 5 years of experience in the care of patients with CP. This work consisted of three steps: elaboration of the questionnaires for validation of the booklet by the judges, interview, and validation of the content.

\section{Elaboration of the questionnaires}

The questionnaires were elaborated based on the evaluation criteria to validate educational material, the Suitability Assessment of Materials $(\mathrm{SAM})^{16}$. This method consists of evaluating the written content in terms of understanding, described as the relative difficulty in understanding the meaning. For this, the questions applied had as answer option the degree of understanding, and these answers were graded in the Likert scale from " 1 " to " 4 ", corresponding to "no," "little," "considerable" and "totally, respectively.

\section{Interview}

Four members of the research group conducted the interview. Initially, the purpose of the study and a brief introduction about the content of the booklet was presented to the volunteers by agreeing to participate and being in compliance with the inclusion and exclusion criteria, the volunteer signed the Free and Informed Con- sent Form (FICT) and received a copy of the booklet to read. The reading occurred in a waiting room and the time available to do it was according to the individual need of each judge. The evaluation questionnaire was applied immediately after. The evaluators guaranteed the confidentiality of the answers by not identifying the judges, and the answers were filed for later analysis.

\section{Content validation}

The Content Validity Index (CVI) was used to validate the educational pain booklet by items ${ }^{17,18}$ considering a cut-off point for approval of equal or above $78 \%$ when there are seven or more judges and $86 \%$ for six judges ${ }^{19}$. The CVI evaluates the proportion of evaluators who judged certain aspects of the booklet as satisfactory, which were assessed through the structured questionnaire. The items of the questionnaires that had a score of 1 and 2 were classified as unsatisfactory answers, and those with a score of 3 or 4 were classified as satisfactory. The final score was calculated from the number of evaluators who judged each item as satisfactory, divided by the number of evaluators:

$$
\text { CVI }=\frac{\text { number of answers } 3 \text { or } 4}{\text { total number of evaluators }}
$$

This study was approved by the Research Ethics Committee of the Institute of Health Sciences of UFBA of 2015 with number 44318415.7.0000.5662. All the recommendations of Resolution 466/12 of the National Health Council that comply with the Declaration of Helsinki have been expressly complied with.

\section{RESULTS}

For the validation process of the booklet, 60 patients with $\mathrm{CP}$ and six health professionals with experience in the care of this population were interviewed. Table 1 shows the level of education and gender of the judges interviewed. Most of the interviewed patients were female $(83.3 \%)$ with complete elementary school (38.3\%) and secondary school (38.3\%). As for the health professionals, $83.3 \%$ had complete higher education (Table 1), while only $6(10.0 \%)$ patients had this level of education.

Table 1. Educational level of the judges expressed in absolute and relative frequency

\begin{tabular}{lcc}
\hline Variables & $\begin{array}{c}\text { Patients } \\
(\mathrm{n} \text { and \%) }\end{array}$ & $\begin{array}{c}\text { Health professionals } \\
(\mathrm{n} \text { and \%) }\end{array}$ \\
\hline Education & & \\
Incomplete elementary school & $4(6.6)$ & - \\
Complete elementary school & $23(38.3)$ & - \\
Incomplete secondary school & $4(6.6)$ & - \\
Complete secondary school & $23(38.3)$ & - \\
Complete higher education & $6(6.10)$ & $5(83.3)$ \\
Complete vocational course & - & $1(16.6)$ \\
Gender & & \\
Male & $10(16.6)$ & $2(33.3)$ \\
Female & $50(83.3)$ & $4(66.6)$ \\
Total & $60(100)$ & $6(100)$ \\
\hline
\end{tabular}


Structured questionnaires were prepared for the validation of the educational booklet by the judges. One questionnaire was directed to patients and one to health professionals.

The questionnaire for patients (Figure 1A) had five domains: content, presentation of the literature, illustration, readability, printing, and overall evaluation. The questionnaire for health professionals (Figure 1B) had six domains, the ones already cited plus scientific accuracy. The questionnaires for patients and health professionals had 22 and 24 questions, respectively. After the questions of each domain, there was some space available for comments and suggestions for adjustments by the judges.

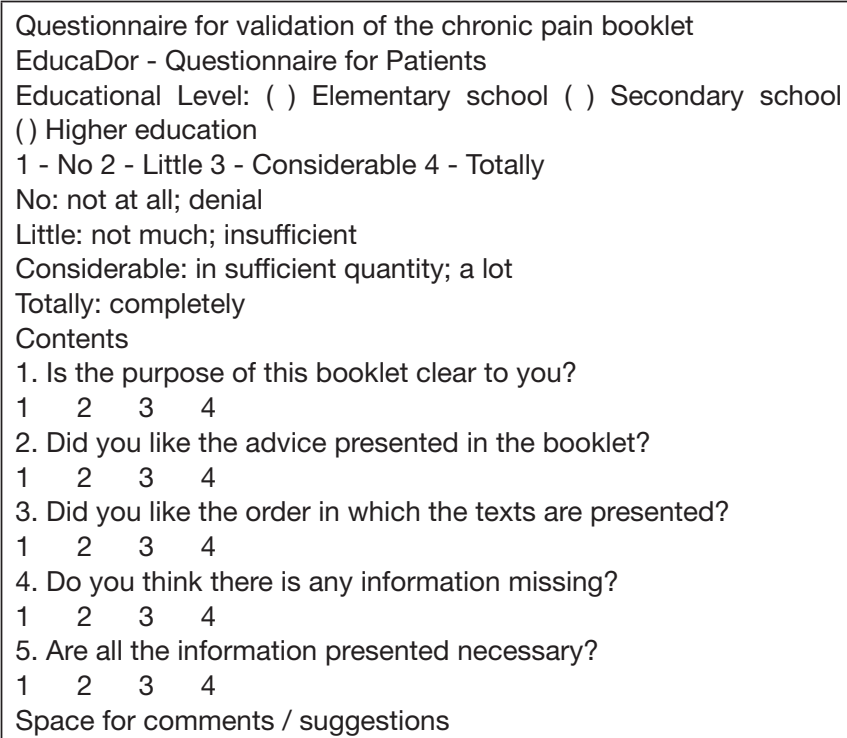

Figure 1A. Questionnaire for patients

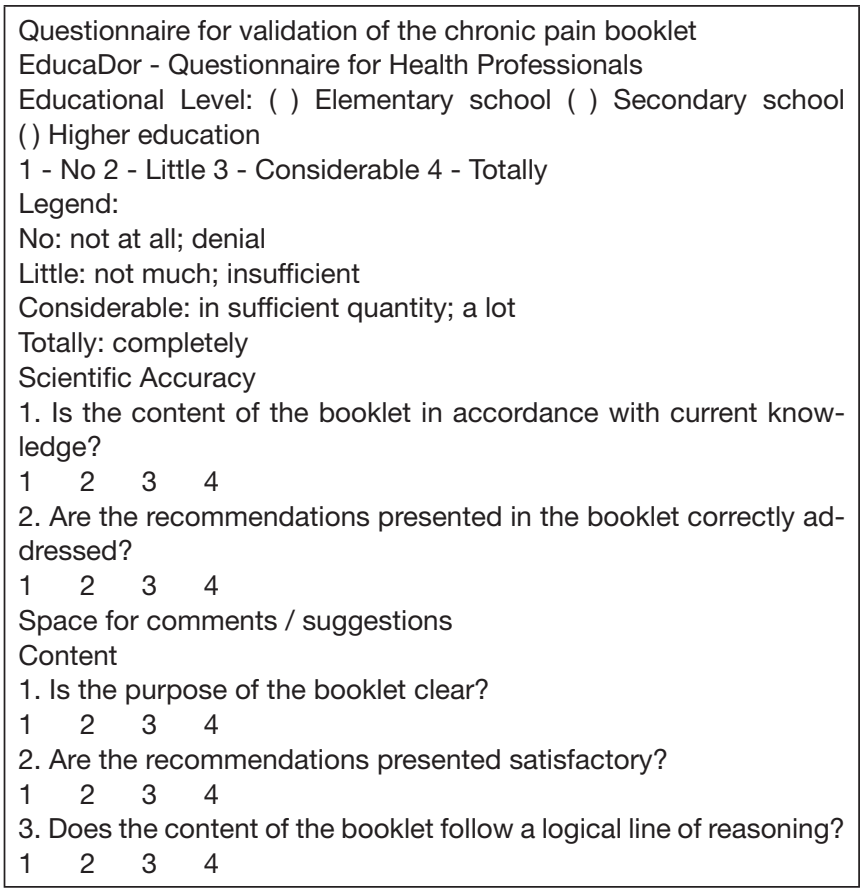

Figure 1B. Questionnaire for health professionals
The final score of the questionnaires was based on CVI. The total number of answers that categorized the items of the booklet as satisfactory were recorded. The analysis was performed for each domain of the questionnaire, and at the end, the value of the total CVI was calculated, obtaining the value of 88 and $92 \%$ for patients and health professionals, respectively (Table 2).

Table 2. Values of the Content Validity Index by item by domain

\begin{tabular}{lcc}
\hline Domains & $\begin{array}{c}\text { Patients } \\
(\%)\end{array}$ & $\begin{array}{c}\text { Health } \\
\text { professionals (\%) }\end{array}$ \\
\hline 1. Scientific accuracy & NA & 100 \\
2. Contents & 87 & 92 \\
3. Presentation of the literature & 86 & 90 \\
4. Illustration & 84 & 88 \\
5. Readability and printing & 94 & 94 \\
6. Overall evaluation & 88 & 100 \\
Total CVI & 88 & 92 \\
\hline
\end{tabular}

$\mathrm{NA}=$ not applicable.

\section{DISCUSSION}

This study aimed to validate a socio-educational material on CP in the format of a booklet that have been developed in a previous study ${ }^{14}$, to check if it could be applied as a health education resource, from the perspective of patients and specialized professionals. The final scores of the evaluation reached a level of excellence in the agreement of the judges and indicated that the EducaDor booklet is valid and can be used as a therapeutic resource.

Several factors have been pointed out as predictors of CP, among them, be female and have a low level of schooling ${ }^{20,21}$. Differences in pain perception between genders are well evidenced in the literature ${ }^{22-25}$. Experimental studies with animals $s^{26,27}$ and humans ${ }^{28}$, support the hypothesis that women have higher pain perception because they are more exposed to specific situations such as dysmenorrhea and childbirth. The education level lower than 11 years has been pointed out as the major risk factor for this condition ${ }^{29}$. The sociodemographic characteristics of the sample of patients interviewed were compatible with the profile cited in these previous studies. Precisely because of this profile, the use of socio-educational materials may be fundamental for health literacy, which may have an impact on pain relief ${ }^{30}$.

The professionals interviewed attributed 100\% scientific accuracy to the material evaluated. This score gives confidence for the immediate adoption of the material by other professionals in clinical practice. Careful professionals have uncertainties in reinforcing erroneous beliefs commonly found in websites and instruction materials not based on science. Due to the multifactorial characteristic of the $\mathrm{CP}$ and the information available on the internet, coping with the problem has been a challenge for health professionals? ${ }^{9}$. The knowledge about pain with a scientific basis comes as a supporting strategy for the treatment of people with CP. Pain education programs use approaches that allow providing information on pain etiology, nosology and 
pain pathophysiology. This type of approach makes it possible to equip patients for greater awareness of the different causal and aggravating factors. The knowledge acts in the social representations and the experiences of the disease, facilitating its recovery ${ }^{31}$. Ease of reading and printing were the best-evaluated items, both by professionals and patients. This result shows the importance of careful preparation of the printed material so that it has sufficient durability to be consulted several times and fulfill its purpose ${ }^{8}$. A systematic review ${ }^{32}$ pointed out that socio-educational programs have an influence on the improvement of pain and movement, and in minimizing disabilities and reducing the utilization of health services. The recognition of the quality of the "EducaDor" booklet may indicate that this tool can be an aid in the treatment of CP in Brazil, due to the biopsychosocial aspects involved ${ }^{14}$.

The elaboration of printed educational material is a means of communication between the health professional and the patient that not only requires a clear identification of the target audience but a direct and intuitive way to convey the content addressed. To raise and keep the interest of the reader, one must consider the language, layout, and illustration. However, it is the illustration that will, by far, ensure the readability and the comprehension of a text ${ }^{33}$. In the "content" domain of the questionnaire, patients and professionals were asked about the clarity of the purpose of the booklet, the comprehension of the text, the order of the texts and the need for information. Approximately $87 \%$ of the patients and $92 \%$ of the professionals judged the content to be satisfactory. However, the illustration had the lowest score in the patients' view (84\%). Although it is a satisfactory level, future editions should consider the possibility of improving the illustrations. Limit the number of illustrations, make them simpler and more representative, emphasizing important points in the text description, listing real-life events are strategies that facilitate the communication of content to the reader. Thus, people with low schooling can benefit from these materials and types of language ${ }^{33}$.

"EducaDor" tried to explain the concept of pain in a clear and detailed way, addressing acute and chronic pain, their characteristics and differences, processing, coping approaches and misbeliefs that patients and caregivers have concerning pain. So far, there are no validated educational booklets for patients with $\mathrm{CP}$ in Brazil. However, several educational materials are available on websites for this population. In addition to addressing concepts, these materials also discuss sleep quality, anxiety, and pharmacological and non-pharmacological treatments. Increasing evidence shows that knowing the neurophysiology of pain helps to reduce the incapacity and catastrophization of patients with CP, improving physical movements and compliance with several therapies ${ }^{34}$. Although the "EducaDor" does not address the treatments for CP, the themes are explained from the stories, questions, and fears reported by this population. The text presents reports of experiences of people who live with pain, allowing the reader to identify himself with the content exposed.

As a limitation, we can mention that this booklet is validated for only one reference pain center, located in Salvador, Bahia, that has specific sociocultural characteristics. Moreover, the small number of health professionals interviewed may not express what the experts from other regions would consider relevant. It is suggested that the EducaDor booklet is validated in other pain centers in other Brazilian regions and its effect on the intensity and other phenomena related to CP be tested in a randomized clinical trial.

\section{CONCLUSION}

Patients suffering from chronic pain and health professionals specialized in its treatment validated the content, the adopted language, the topics covered and the illustrations of the EducaDor booklet.

\section{REFERENCES}

1. Williams AC, Craig KD. Updating the definition of pain. Pain. 2016;157(11):2420-3.

2. Teixeira M, Teixeira W, Santos F, Andrade D, Bezerra S, Figueiró J, et al. Epidemiologia clínica da dor músculo-esquelética. Rev Med. 2001;80(spe1):1-21.

3. Sá K, Baptista AF, Matos MA, Lessa I. Chronic pain and gender in Salvador population, Brazil. Pain. 2008;139(3):498-506.

4. Ferreira Kdos S, Oliver GZ, Thomaz DC, Teixeira CT, Foss MP. Cognitive deficits in chronic pain patients, in a brief screening test, are independent of comorbidities and medication use. Arq Neuropsiquiatr. 2016;74(5):361-6.

5. McGillion MH, Watt-Watson J, Stevens B, Lefort SM, Coyte P, Graham A. Randomized controlled trial of a psychoeducation program for the self-management of chronic cardiac pain. J Pain Symptom Manage. 2008;36(2):126-40.

6. Haugli L, Steen E, Laerum E, Nygard R, Finset A. Learning to have less pain - is it possible? A one-year follow-up study of the effects of a personal construct group learning programme on patients with chronic musculoskeletal pain. Patient Educ Couns. 2001;45(2):111-8

7. Moseley L. Combined physiotherapy and education is efficacious for chronic low back pain. Aust J Physiother. 2002;48(4):297-302.

8. Moseley GL, Nicholas MK, Hodges PW. A randomized controlled trial of intensive neurophysiology education in chronic low back pain. Clin J Pain. 2004;20(5):324-30.

9. Louw A, Zimney K, O'Hotto C, Hilton S. The clinical application of teaching people about pain. Physiother Theory Pract. 2016;32(5):385-95.

10. Meeus M, Nijs J, Oosterwijck J, Van Alsenoy V, Truijen S. Pain physiology education improves pain beliefs in patients with chronic fatigue syndrome compared with pacing and self-management education: a double-blind randomized controlled trial. Arch Phys Med Rehabil. 2010;91(8):1153-9.

11. Ryan RM, Weinstein N, Bernstein J, Brown KW, Mistretta L, Gagné M. Vitalizing effects of being outdoors and in nature. J Environ Psychol. 2010;30(2):159-68.

12. Gallagher L, McAuley J, Moseley GL. A randomized-controlled trial of using a book of metaphors to reconceptualize pain and decrease catastrophizing in people with chronic pain. Clin J Pain. 2013;29(1):20-5.

13. van Ittersum MW, van Wilgen CP, van der Schans CP, Lambrecht L, Groothoff JW, Nijs J. Written pain neuroscience education in fibromyalgia: a multicenter randomized controlled trial. Pain Pract. 2014;14(8):689-700.

14. Mendez SP, Sá KN, Araújo PC, Oliveira IA, Gosling AP, Baptista AF. Desenvolvimento de uma cartilha educativa para pessoas com dor crônica. Rev Dor. 2017;18(3):199-211.

15. Joventino ES, Oriá MO, Sawada NO, Ximenes LB. Apparent and content validation of maternal self-efficiency scale for prevention of childhood diarrhea. Rev Lat Am Enfermagem. 2013;21(1):371-9.

16. Doak CC, Doak LG, Root JH. Learner Verification and Revision of Materials. In Doak, CC, Doak LG, Root JH. Teaching Patients with Low Literacy Skills. 1996. $2^{\text {nd }}$ ed. Philadelphia: Lippincott Company; 1996. 167-88p.

17. Alexandre NM, Coluci MZ. Validade de conteúdo nos processos de construçấo e adaptação de instrumentos de medidas. Ciênc Saúde Coletiva. 2011;16(7):3061-8.

18. Polit, DE, Beck CT. Essentials of Nursing Research. $6^{\text {th }}$ Ed. Philadelphia: Lippincott Williams \& Wilkins; 2006.

19. Coluci MZ, Alexandre NM, Milani D. Construção de instrumentos de medida na área da saúde. Ciênc Saúde Coletiva. 2015; 20(3):925-36.

20. Sá K, Baptista AF, Matos MA, Lessa I. Prevalence of chronic pain and associated factors in the population of Salvador, Bahia. Rev Saude Publica. 2009;43(4):622-30. English, Portuguese.

21. Malta DC, Oliveira MM, Andrade SS, Caiaffa WT, Souza MF, Bernal RT. Factors associated with chronic back pain in adults in Brazil. Rev Saude Publica. 2017;51(Suppl 1):9s. English, Portuguese.

22. Palmeira CC, Ashmawi HA, Posso IP. Sexo e percepção da dor e analgesia. Rev Bras Anestesiol. 2011;61(6):820-8.

23. Greenspan JD, Craft RM, LeResche L, Arendt-Nielsen L, Berkley KJ, Fillingim RB, et al. Studying sex and gender differences in pain and analgesia: a consensus report. Pain. 2007;132(Suppl 1):S26-45.

24. Unruh AM. Gender variations in clinical pain experience. Pain. 1996;65(2-3):123-67. 
25. Riley J 3rd, Robinson ME, Wise EA, Myers CD, Fillingim RB. Sex differences in the perception of noxious experimental stimuli: a meta-analysis. Pain. 1998;74(2-3):181-7.

26. Fillingim RB, Gear RW. Sex differences in opioid analgesia: clinical and experimental findings. Eur J Pain. 2004;8(5):413-25.

27. Thompson AD, Angelotti T, Nag S, Mokha SS. Sex-specific modulation of spinal nociception by alpha2-adrenoceptors: differential regulation by estrogen and testosterone. Neuroscience. 2008;153(4):1268-77.

28. Lira MO, Carvalho MF. Dor aguda e relação de gênero: diferentes percepçóes em homens e mulheres. Rev Rene. 2013;14(1):71-81.

29. Sardá Jr JJ, Nicholas MK, Pimenta CA, Asghari Ali. Preditores biopsicossociais de dor, incapacidade e depressão em pacientes brasileiros com dor crônica. Rev Dor.
2012;13(2):111-8

30. Santos ML, Paixão RL, Osorio-de-Castro CG. Avaliação da alfabetização em saúde do sujeito de pesquisa. Rev Redbioética/UNESCO. 2013;1(7):84-95.

31. Gazzinelli MF, Gazzinelli A, Reis DC, Penna CM. [Health education: knowledge, social representation, and illness]. Cad Saude Publica. 2005;21(1):200-6. Portuguese.

32. Vieira A, Braga RM, Bartz PT, Candotti CT. Efetividade da escola postural em portadores de dor lombar crônica inespecífica. Acta Fisiatr. 2012;19(3):184-91.

33. Moreira MF, Nóbrega MM, Silva MI. Comunicação escrita: contribuiçâo para a elaboração de material educativo em saúde. Rev Bras Enferm. 2003;56(2):184-8.

34. Louw A, Puentedura EL. Therapeutic neuroscience education, pain, physiotherapy and the pain neuromatrix. Int J Health Sci. 2014;2(3):33-45. 